\title{
Maternal voice and preterm infants development
}

\author{
Giancarlo Gargano*, Francesca Nuccini \\ From XXI Congress of the Italian Society of Neonatology \\ Palermo, Italy. 24-26 September 2015
}

Mother's voice seems to have an important role in neurological development of the fetus and the newborn.

Numerous studies have shown that the fetus perceives sounds and reacts to them since 26 th-28th week of gestation and that he has the ability to discriminate between the maternal voice and other voices, showing a marked preference to the first $[1,2]$.

The fetus within the uterus is in a sound environment, called "noise floor", resulting from the combination of "internal noise", such as the sound of maternal heartbeat, breathing and gastrointestinal activity, and "external noise", principally the mother's voice.

Premature birth abruptly stops prenatal learning experiences and it causes a sudden transition from the quiet and lovely environment of the maternal womb, towards the noisy world of the NICU, often hostile and aggressive [3]. During the months in NICU, the baby is deprived of the biological maternal sounds and this could interfere with his neurodevelopment, in particular speech and language acquisition.

The Developmental Care programs aim to provide an extra-uterine environment similar to the maternal womb: control of light, noise, pain, postural care, kangaroo mother care are examples. Few studies addressed the beneficial effects of the early exposure to the mother's voice and recently some researches have shown that this sound can increase cardiorespiratory stability and growth, improve deep sleep, and shorten length of hospital stay [4-8].

In 2013 Loewy [9], using several acoustic stimuli, has shown that exposure to "intrauterine" stimuli and in particular to the mother's voice, meant an increased attention span and alertness, associated with a marked reduction in heart rate, increased stability of behavioral states and sleep quality and improved nutritional behavior and caloric intake.

\footnotetext{
* Correspondence: giancarlo.gargano@asmn.re.it Neonatologia e Terapia Intensiva Neonatale, Arcispedale S. Maria Nuova -
} IRCCS, Reggio Emilia, Italy

\section{References} discrimination of speech stimuli; demonstration by cardiac reactivity. $C R$ Acad Sci III 1987, 305(5):161-164.

2. Kisilevsky BS, Hains SM, et al: Fetal sensitivity to properties of maternal speech and language. Infant Behav Dev 2009, 32(1):59-71.

3. Picciolini $O$, Porro $M$, et al: Early exposure to maternal voice: effects on preterm infants development. Early Hum Dev 2014, 90(6):287-292.

4. Beauchemin M, González-Frankenberger B, Tremblay J, et al: Mother and stranger: an electrophysiological study of voiceprocessing in newborns. Cereb Cortex 2011, 21(8):1705-1711.

5. Arnon S, Shapsa A, Forman $L$, et al: Live music is beneficial to preterm infants in the neonatal intensive care unit environment. Birth 2006, 33(2):131-136.

6. Blumenfeld $H$, Eisenfeld $L$ : Does a mother singing to her premature baby affect feeding in the neonatal intensive care unit? Clin Pediatr (Phila) 2006, 45(1):65-70.

7. Zimmerman $E$, Keunen $\mathrm{K}$, Norton M, Lahav A: Weight gain velocity in very low-birthweight infants: effects of exposure to biological maternal sounds. Am J Perinatol 2013, 30(10):863-870.

8. Krueger C: Exposure to maternal voice in preterm infants: a review. Adv Neonatal Care 2010, 10(1):13-18.

9. Loewy J, Stewart K, et al: The effects of music therapy on vital signs, feeding, and sleep in premature infants. Pediatrics 2013, 131(5):902-918. 
10. Chorna OD, Slaughter JC, et al: A pacifier-activated music player with mother' voice improves oral feeding in preterm infants. Pediatrics 2014, 133(3):462-468.

doi:10.1186/1824-7288-41-S1-A14

Cite this article as: Gargano and Nuccini: Maternal voice and preterm infants development. Italian Journal of Pediatrics 2015 41(Suppl 1):A14.

Submit your next manuscript to BioMed Central and take full advantage of:

- Convenient online submission

- Thorough peer review

- No space constraints or color figure charges

- Immediate publication on acceptance

- Inclusion in PubMed, CAS, Scopus and Google Scholar

- Research which is freely available for redistribution

Submit your manuscript at www.biomedcentral.com/submit
() Biomed Central 